\title{
Comparative Analysis of Performance Indonesia with the Philippines Banking Stock Using the Sharpe, Treynor, and Jensen Index
}

Arief Rahman

Master of Management, Faculty of Economics and Social Sciences, Bakrie University, Indonesia

\begin{abstract}
Article Info

Volume 8, Issue 2

Page Number : 553-563

Publication Issue

March-April-2021

\section{Article History}

Accepted : 20 April 2021

Published : 25 April 2021

This study aims to analyze the comparison of the performance of banking stocks on the LQ 45 index in Indonesia and the Philippines PSEi during the 2014-2018 period. This type of research is descriptive with a quantitative approach. The research used is to calculate the return and risk of banking stocks. For further analysis, it measures performance based on the Sharpe, Treynor, and Jensen indexes. Comparative testing was performed using the Independent Sample T-Test. Based on the return calculation, Indonesian banking stocks have a significantly greater return than the Philippines. As for the risk, there is no significant difference, but the risk of Indonesian banking stocks is relatively greater. Performance measurement results based on the index of Sharpe, Treynor, and Jensen is the Indonesian banking stocks relative performance is better than the Philippine banking stocks, although there was no significant difference.
\end{abstract}

Keywords : Banking Stocks, LQ 45, PSEi, Sharpe Index, Treynor Index, Jensen Index, T- Test

\section{INTRODUCTION}

\subsection{Background}

The enactment of the ASEAN Economic Community (MEA), is generally defined as an integrated community with one another, where there is free trade among ASEAN member countries aiming to transform ASEAN into a more stable and competitive in economic development. With the MEA, it will make it easy for a number of foreign securities companies to offer products throughout the ASEAN region and encourage local companies to list their shares in the capital markets of other countries.

Indonesia and the Philippines are increasingly being looked at by foreign countries as investment destinations. The report released by US News named the Philippines and Indonesia as the world's first and second-best investment destinations. Indonesia is considered to have relatively stable economic growth in the coming years as well as policy reforms that are combined with national economic performance. The Philippines is aggressively accepting increased foreign 
investment from strong economies such as China. One of the advantages of this country is a trained workforce with relatively affordable wages. The countries of Indonesia and the Philippines share the same socio-economic sector with the fastest economic growth trend in other ASEAN countries. In addition to the economic sector which is growing quite rapidly. Currently, Indonesia and the Philippines have the majority of the population in their productive age. The banking sector in Indonesia and the Philippines has several financial indicators in common, including the ratio of domestic credit to Gross Domestic Product (GDP) in the range of 33.8\% and $43.6 \%$ in 2016, supported by strong capital.

Many stock market analysts argue that the drop in banking shares, in general, occurs because of three things that last year the banking stock price has gone up high, economic conditions such as the trade war between the US and China that could lead to recession, and rising interest rates. The financial sector has the largest market capitalization 31.05\%. Some capital market experts, the prospects in the financial sector is still good, especially for banks are still attractive for their collection. This is because, in general, banks are still solid fundamentals and a decline in stock prices in the market sentiment due to the external sector [1].

An important step in the investment process is the portfolio performance evaluation stage. Several factors are concerned in evaluating portfolio performance including the level of risk, time period, selection of appropriate benchmarks, and investment objectives [2]. There are several methods that are relevant in measuring the performance of the portfolio based on risk and return is the Sharpe index, Treynor index, and Jensen index [3]. Sharpe index aims to compare portfolios against overall risk. Treynor Index is based on the same thing as the Sharpe index which forms the portfolio of the systematic risk is the market risk. While the Jensen index can be interpreted as a measure of how much of the portfolio beat the market.

This study will assess the performance of stock investment in Indonesia through the capital market indicator that will be compared to the Philippines. The object of the research is banking shares incorporated or listed in LQ 45 index PSEi to Indonesia and the Philippines. Stocks that are incorporated in the index are stocks that have high liquidity and large market capitalization and supported by the company's fundamentals are good. The sample data used data with coverage year period 2014-2018. This research is the development of a research conducted by Akbar (2017) that analyzes the comparative performance of shares on the stock exchanges of ASEAN, namely Indonesia, Malaysia, Philippines, Singapore, and Thailand.

Based on this background, the researchers are interested in doing research titled "Comparative Analysis Stock Performance Banking Indonesia and the Philippines Using Sharpe, Treynor, and Jensen Index"

\subsection{Problem Formulation}

Based on the description above, the problems to be discussed in this study can be formulated as follows:

1. What is the description of the performance of banking stocks in Indonesia and the Philippines based on the Sharpe, Treynor, and Jensen Index?

2. How comparative analysis of the performance of banking stocks between Indonesia and the Philippines produces the best performance based on the Sharpe, Treynor, and Jensen Index?

\subsection{Research Objective}

In accordance with the formulation of the problem already described above, the objectives of this research are:

1. Analyzing the performance of Indonesian and Philippine banking stocks for the period 2014- 
2018 based on the measurement of the performance of the Sharpe, Treynor, and Jensen Index.

2. Comparing the performance of banking stocks in Indonesia and the Philippines

\subsection{Research Benefit}

This research is expected to provide contributions and benefits to various parties, including:

1. For investors expected to provide an overview that will invest in stocks, especially banking stock instruments, to make investment decisions that can maximize the return and minimize the risk by considering the performance of the stock instrument and not overriding any consistency factor of an investment manager.

2. For academics and researchers in the education sector, this research can be used as a reference and add to the study materials and literature on capital markets in particular stocks. Moreover, providing additional insights and views on the performance of a stock portfolio with index method Sharpe, Treynor, and Jensen Index in a diversified stock.

3. Provide information to the investment manager, to always do the evaluation and improvement of the investment is managed.

\section{LITERATURE REVIEW}

\subsection{Return}

Return is the result obtained from the realization of investment activities in the form of return and return expectations [4]. Form of return can be a return realization that has happened and return expectations that have not happened yet, but investors are expected to occur in the future. In measuring realized return, total return is widely used, which is the total return of an investment in a certain period. In this return, the calculation is based on historical data. This realized return can be used as a measure of company performance and the basis for determining future return expectations and risks. Conversely, the expected return is the return that investors expect to receive in the future.

\subsection{Risk}

Risk is defined as the uncertainty of the results obtained in the future or the chance of loss of revenue in the future [5]. Standard deviation calculation stating the magnitude of expected risk. In principle, the risk can be divided into two parts, namely [6]:

1. Non-systematic Risk

The risks associated with a stock can generally be avoided or minimized. This risk is often referred to as a specific risk or company risk. Non-systematic risk can generally be managed using the portfolio, such as through diversification.

2. Systematic Risk

Market risk is of a general nature and applies to all stocks in the capital market is concerned. This type of risk cannot be avoided by investors even through diversification. An example is an increase in interest rates (interest-rate risk), rising inflation (inflationary risk), and high market volatility (market risk). Systematic risk measurement of a portfolio or security can be calculated using the beta. To calculate the portfolio beta, the beta of each security must be known in advance because the beta of a portfolio is the weighted average of the beta of any securities. A security's beta is the return covariance between the $i$-th security and the market return divided by the variance of the market return.

\subsection{Composite Stock Price Index (IHSG)}

An index to measure the movement of all shares listed on the Indonesia Stock Exchange. According to [7], the Stock Price Index is an indicator that shows stock price movements. The index serves as an indicator of market trends, where the movement of the index describes market conditions when the market is active or sluggish. IHSG is strongly influenced by stocks that have large market capitalization, which is often called the index movers or movers stock index. IHSG is commonly known as the JKSE code. 


\subsection{PSEI Index}

If in Indonesia using the IHSG, to the Philippines using PSEi. Philippine Stock Exchange Composite Index (PSEi), formerly named Phisix, are 30 companies listed, carefully selected to represent the general movement of the stock market. In other words, this is a benchmark that measures the performance of the Philippine stock market. Consisting of stock representatives from Industry, Property, Services, Holding Companies, the Financial Sector, Mining and Oil.

\subsection{Sharpe Index}

Sharpe is often referred to as the Reward to Variability. Sharpe measure against the return of a portfolio standard deviation or total risk. This method uses the concept of a capital market line as a benchmark by dividing the portfolio risk premium by its standard deviation [8]. In portfolio theory, the standard deviation is the sum of the total risk of market risk (systematic) and unique risk (nonsystematic). Sharpe index takes into account three things: the portfolio return, standard deviation, and the risk-free rate.

If the Sharpe index value is positive and the greater the portfolio performance is getting better. The portfolio with the highest Sharpe ratio performed the best and vice versa. To determine the ranking of the portfolio, the Sharpe ratio of the portfolio should be compared with the Sharpe ratio of the portfolio of another.

\subsection{Treynor Index}

Treynor Index is commonly called the concept of the securities market line, which defines the relationship between the portfolio return to the market, where the slope of the line measures the relative volatility of the portfolio to the market (beta). In principle, the beta coefficient is used to measure the volatility of the stock, portfolio, or the market itself. The bigger the slope of the line, the better the trade-off. Treynor
Index takes into account three things: the return of portfolio, risk-free rate, and beta portfolios.

If the Treynor index value is positive and the greater the portfolio performance is getting better. Treynor ratio is a simple extension of the Sharpe ratio and completes the first restrictions Sharpe ratio by replacing the beta risk with total risk. [3]

\subsection{Jensen Index}

This index measures the difference between the actual return and the CAPM based on the same risk (beta) [9]. This identifies the ability of active management to improve returns more as a reward from risk. Jensen is very concerned at CAPM to measure the performance of the portfolio which is often called ALPHA Jesen.

The Jensen Index value $\left(\hat{\alpha}_{p}\right)$ shows whether the portfolio has outperformed the market. If $\hat{\alpha}_{p}$ positive, then the portfolio has outperformed the market; if $\hat{\alpha}_{p}$ is negative, the portfolio has underperformed the market. A positive index means that the portfolio provides a return greater than the expected return, so it is a good thing because a portfolio has a relatively high return for its level of systematic risk.

\subsection{Independent T-Test}

Test T serves as a data analysis tool to test one or two populations population and compare the two mean (average) to determine whether there are differences in average real differences or due to chance. Before the independent T-test was carried out, the data normality test was carried out. If the data are normally distributed, then tested the homogeneity or variance to test F-test or Levene's Test.

The decision is based on a comparison of the significant value in a test independent sample $t$-test is based on the basis of a decision as follows: [10]

- If Sig. (2-tailed) >0,05 then accept $\mathrm{H}_{0}$

There were no differences in average significantly

- If Sig. (2-tailed) $<0,05$ then accept $\mathrm{H}_{1}$

There are differences in the average significantly 


\section{RESEARCH METHODOLOGY}

\subsection{Data Source}

Sources of data used in this study using a nonparticipant observation. Non-participant observation carried out by observing and recording all the data required in this study of historical data monthly closing price of bank shares state of Indonesia and the Philippines. The data used in this study used secondary data collected in the 2014-2018 period. Data is internal or external organizations and accessed via the internet or publication of information.

1. The closing price of monthly banking shares that entered LQ-45 from the Indonesia Stock Exchange (IDX) and the PSEi composite index from the Philippine Stock Exchange

2. The interest rate on Bank Indonesia SBI report, central statistical agency (BPS), and BSP Central Bank of the Philippines.

3. The market price index derived from IHSG and PSEi

\subsection{Determination of Stocks}

The period in the determination of the stock in this study period from 2014 until 2018. Where such shares are entered into the category of index LQ-45 and PSEi. Only select banking stocks that are listed on the LQ45 index and the PSEi composite index for 5 consecutive observation periods during the 2014 2018 period

Table 3.1 object of research

\begin{tabular}{|c|c|l|}
\hline Country & Code & \multicolumn{1}{|c|}{ Emitten } \\
\hline \multirow{3}{*}{ Indonesia } & BMRI & $\begin{array}{l}\text { PT Bank Mandiri } \\
\text { (Persero) Tbk }\end{array}$ \\
\cline { 2 - 3 } & BBRI & $\begin{array}{l}\text { PT Bank Rakyat Indonesia } \\
\text { (Persero) Tbk }\end{array}$ \\
\cline { 2 - 3 } & BBNI & $\begin{array}{l}\text { PT Bank Negara Indonesia } \\
\text { (Persero) Tbk }\end{array}$ \\
\hline
\end{tabular}

\begin{tabular}{|c|c|l|}
\hline & BBCA & PT Bank Central Asia Tbk \\
\hline \multirow{4}{*}{ Philippine } & BDO & BDO Unibank, Inc. \\
\cline { 2 - 3 } & BPI & $\begin{array}{l}\text { Bank Of The Philippine } \\
\text { Islands }\end{array}$ \\
\cline { 2 - 3 } & MBT & $\begin{array}{l}\text { Metropolitan Bank \& } \\
\text { Trust Company }\end{array}$ \\
\hline
\end{tabular}

\subsection{Data Analysis}

Analysis of the data used in this research is descriptive quantitative

1. Calculating the average stock return

Comparison of the difference in the percentage of the closing price of the stock [3]

$$
\begin{aligned}
& R_{p(t)}=\frac{P_{t}}{P_{t-1}}-1 \\
& R_{p}=\sqrt[n]{\prod_{t=1}^{n}\left(1+R_{p(t)}\right)}-1 \\
& R_{P}=\left(1+R_{p}\right)^{12}-1 \quad \text { (annualized) }
\end{aligned}
$$

2. Calculating the average return of the market (benchmark)

Comparison of the percentage difference from the closing price of the benchmark index [3]

$$
R_{m(t)}=\frac{I B_{t}}{I B_{t-1}}-1
$$

$$
\begin{aligned}
& R_{m}=\sqrt[n]{\prod_{t=1}^{n}\left(1+R_{m(t)}\right)}-1 \\
& R_{M}=\left(1+R_{m}\right)^{12}-1 \text { (annualized) }
\end{aligned}
$$

3. Calculating of risk free rate [3]

$$
R_{f}=\frac{\text { Srisk free rate }}{n}
$$

4. Calculating the standard deviation

Standard deviation is generated using the following formula [3] 


$$
\begin{aligned}
& \sigma_{p}=\sqrt{\frac{\sum_{t=1}^{n}\left[R_{p(t)}-R_{P}\right]^{2}}{n-1}} \\
& \sigma_{P}=\sigma_{p} \sqrt{T} \text { (annualized) }
\end{aligned}
$$

5. Calculating the Beta value $(\beta)$

Beta is measured by dividing the covariance between market and stock returns by the benchmark variant [3]

$$
\begin{aligned}
& \sigma_{p m}=\frac{\sum_{t=1}^{n}\left[R_{p(t)}-R_{P}\right]-\left[R_{m(t)}-R_{M}\right]}{n} \\
& \beta_{p}=\sigma_{p m} / \sigma_{m}^{2}
\end{aligned}
$$

6. Calculating performance measurement

a. Sharpe Index

The formula used by the Sharpe index is as follows [3]:

$$
\hat{S}_{p}=\frac{R_{P}-R_{f}}{\sigma_{P}}
$$

b. Treynor Index

The formula used by the Treynor index is as follows [3]:

$$
\widehat{T}_{p}=\frac{R_{P}-R_{f}}{\beta_{p}}
$$

\section{c. Jensen Index}

The formula used by the Jensen index is as follows [3]:

$$
\hat{\alpha}_{p}=R_{P}-\left[R_{f}+\left(R_{M}-R_{f}\right) \beta_{p}\right]
$$

7. Comparison with Statistical Test

1) Normality Test

Shapiro-Wilk is one of the normality tests recommended by many researchers if the sample size is small, which is less than or equal to 50 samples $(\leq 50)$ [12]. This test is very sensitive or suitable for detecting any abnormal data distribution. Decision making in the normality test is: [11]
1. If the value of Sig. (Significance) $\leq 0.05$ (Sig. Value greater than 0.05), then the data is not normally distributed

2. If the value of Sig. (Significance) $>0.05$, (the Sig. Value is smaller than 0.05), then the data is normally distributed.

2) T-Test

If the data are normally distributed, then tested the homogeneity of variance to test F-test or Levene's Test

$$
F=\frac{S_{1}{ }^{2}}{S_{2}{ }^{2}}
$$

The T-test for the same variant uses the Polled Variance formula, as follows:

$$
t=\frac{\bar{X}_{1}-\bar{X}_{2}}{\sqrt{\frac{\left(n_{1}-1\right) S_{1}{ }^{2}+\left(n_{2}-1\right) S_{2}{ }^{2}}{n_{1}+n_{2}-2}\left(\frac{1}{n_{1}}+\frac{1}{n_{2}}\right)}}
$$

The T-test for different variants used the separated variance formula, as follows:

$$
t=\frac{\bar{X}_{1}-\bar{X}_{2}}{\sqrt{\frac{s_{1}{ }^{2}}{n_{1}}+\frac{s_{2}{ }^{2}}{n_{2}}}}
$$

\section{ANALYSIS AND DISCUSSION}

\subsection{Banking Stocks Performance Indonesia And Philippines}

1. Return of Indonesian and Philippine Banking Stocks

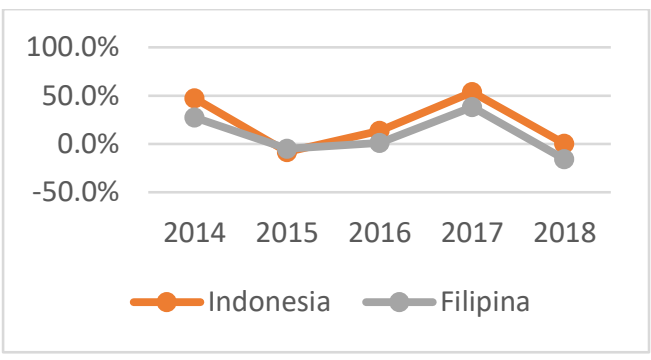

Figure 4.1

Return Chart for Banking Stocks in Indonesia and the Philippines, 2014-2018

Based on Figure 4.1, in 2015, banking stocks in Indonesia and the Philippines experienced a 
decline. It can be seen that the average return in 2015 was negative. This is due to the increase in the Fed's interest rate. The World Bank report, economic big countries and developing ASEAN will be strengthened in 2017. The Philippines benefits from higher public spending on infrastructure, an increase in private investment, credit expansion, and increased income from abroad. Meanwhile, for Indonesia, credit expansion and rising oil prices will boost economic growth in 2017. In 2018, there was a trade war between China and the US that lasted quite a long time. The incidence of severe consequences for investment in world capital markets. Market capitalization, especially for the financial sector in Indonesia, is the largest and most dominant. Where the largest index is a bank. Unlike the Philippines, the financial sector is not the largest capitalization.

2. Banking Stocks Risk of Indonesia and the Philippines

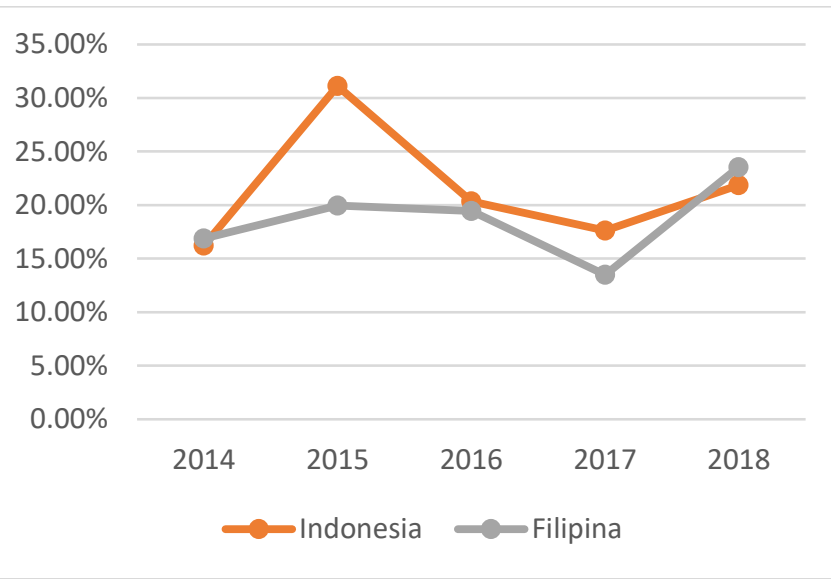

Figure 4.2. Risk Chart for Banking

Stocks in Indonesia and the Philippines, 2014-2018

Based on Figure 4.2, the comparison of risk levels shows that the risk of banking shares in Indonesia and the Philippines shows that Indonesian banking stocks have a greater risk level than the Philippines. In 2018, Bank Indonesia and the Philippines Central Bank raised interest rates five times the impact commencing until economic conditions the US and China trade war. With an increase in interest rates, the company's expenses will increase. Increasing expenses will reduce the level of company profits so that the stock price will also be depressed. This will make investors withdraw their capital from the capital market. Increased borrowing costs and the exchange rate against the US dollar strengthening caused financial pressures in developing countries such as Indonesia and the Philippines. It can trigger risk aversion and asset sales in the financial markets.

3. Banking Stocks Performance with Sharpe Index

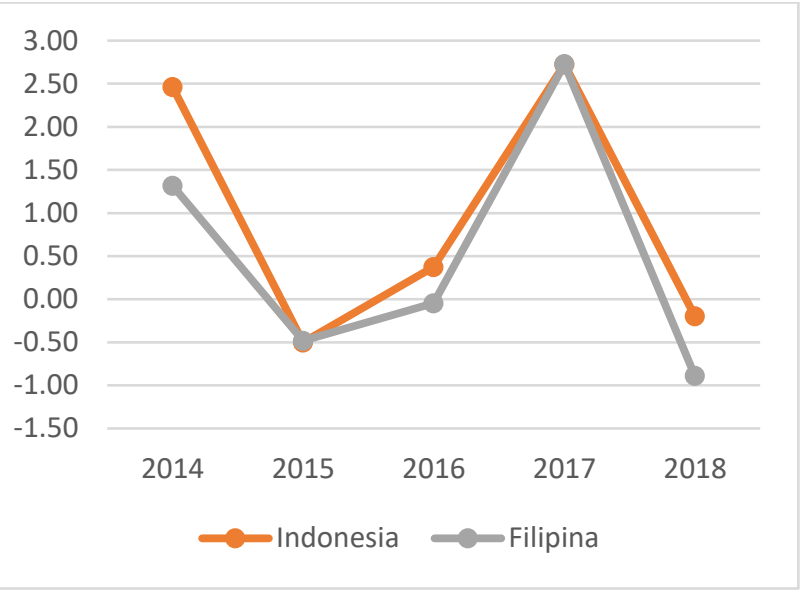

Figure 4.3 Comparison chart of the performance of the Indonesian and Philippine

Banking Stock Sharpe index in 2014-2018

In addition to the increase of the federal funds rate in the US in 2015 that affected the decline in stock prices in the ASEAN, issues related to nonperforming loan (NPL) is a non-performing loan, which is one key to assessing the quality of the bank's performance. If the NPL increases would negatively impact the bank. One negative effect is to reduce the amount of capital owned by banks. NPL trigger factor is the US trade war with China and the weakening of the currency in 2018, the debtor is not able to resolve the problem of bad loans due to high-interest rates. FSA data by the end of 2018, the position of NPL was at $2.2 \%$, the 
ratio is much lower compared to the year 2017 was at the level of $2.59 \%$. As for the Philippines, the NPL ratio at the end of 2018 stood at $1.8 \%$, the ratio was higher at a $1.7 \%$ position in 2017 .

Based on the performance of a financial index, throughout 2018 for Indonesia posted a positive $3.05 \%$ while the Philippines recorded a poor result which fell by $20.19 \%$. This causes excess return Indonesian banking shares is greater than the Philippines for each unit of total risk. That is the advantage to invest in banking stocks Indonesia and the Philippines is greater than the profit of investments in risk-free assets, the benefit of investment in the Indonesian banking shares is greater than the Philippines when viewed from the risk of the total for each index.

4. Banking Stocks Performance with Treynor Index

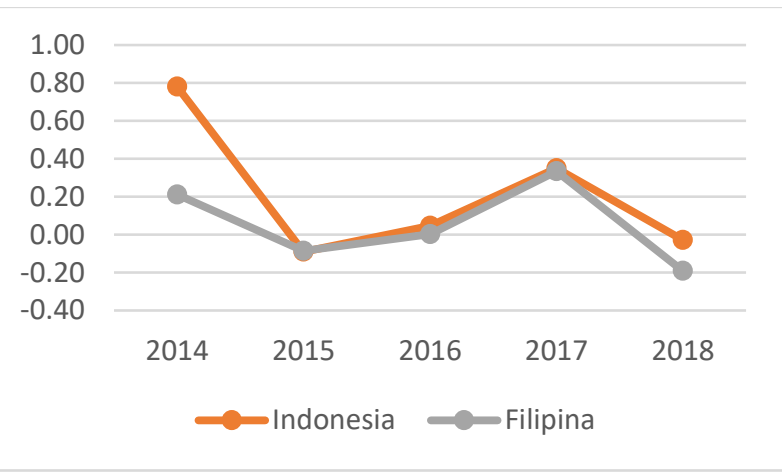

Figure 4.4. Comparison chart of the performance of the Indonesian and Philippine Banking Stock Treynor index in 2014-2018

In 2015 all the performance of banking stocks in Indonesia and the Philippines declined. This is not apart from the crisis global economy and the Fed's interest rate hikes. Especially to the Philippines, they have a huge debt of around 77\% of GDP which inhibits repair of the economic situation of the Philippines. Allocation of funds for debt is higher than in other sectors. The main problem faced by the banking Philippines also of the crisis today is too concentrated bank lending to the corporate sector. As a result, banks are very vulnerable to systemic risks. Another difficulty in making banking supervision in the Philippines is not effective is banking too many banks. This can occur because the central bank has been too focused on payment systems and banking supervision instead.

Indonesia's positive performance in 2016 was supported by a package of government policies that create runaway inflation and a decline in the benchmark interest rate. In addition, a tax amnesty program or a tax amnesty contributed to the positive performance of the capital markets in Indonesia so the impact on stock prices, especially banking stocks.

ASEAN economic growth declined in 2018. According to data collected by the Asian Development Bank (ADB), the economic growth of five ASEAN countries including Indonesia and the Philippines reached $4.8 \%$. In addition to its US and China trade war, countries in the ASEAN region weaken the exchange rate. Philippine economic growth fell from $6.7 \%$ in 2017 to $6.2 \%$. While Indonesia was $5.17 \%$ in 2018 compared to $5.07 \%$ in 2017. This was due to the increase in private consumption, namely the Asian Games.

5. Banking Stocks Performance with Jensen Index

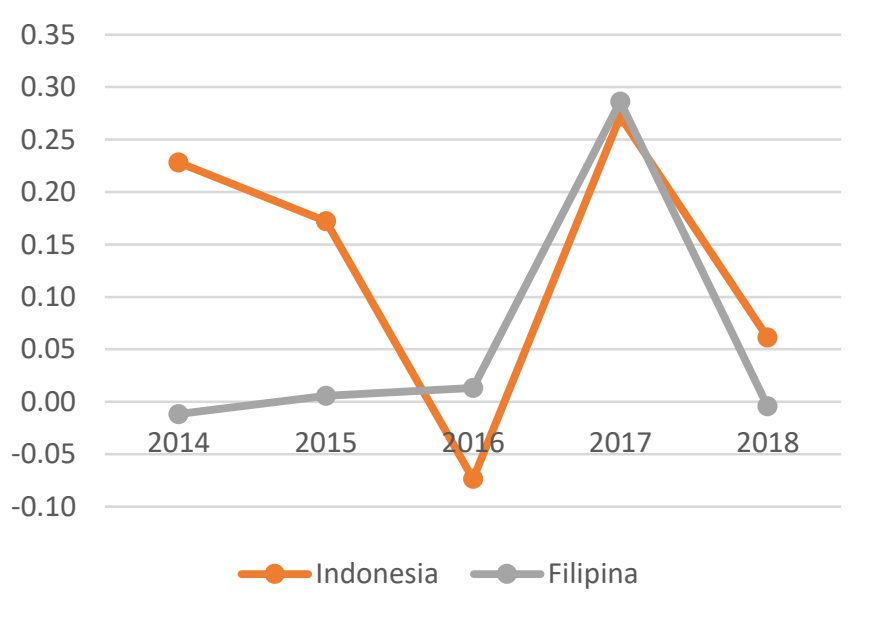

Figure 4.5. Comparison chart of the performance of the Indonesian and Philippine Banking Stock Jensen index in 2014-2018 
Based on the research results and comparisons show Jensen index performance measurement is based on the theory of the Capital Asset Pricing Model (CAPM), which compares the excess return with the required return predicted from the CAPM. Jensen index performance measurement results are positive on banking stocks in both countries. This indicates that investment managers in each country generally perform better than expected. The index of banking stocks is positive means Indonesia and the Philippines provide a return greater than the return expectations (placed above the securities market) so it is a good thing because banks have a relatively high return to the level of systematic risk.

Jensen index measurement acquisition during the period 2014-2018 explained that the investment manager to the Indonesian banking stocks outperformed the Philippines. This suggests that the Indonesian banking stocks have an actual rate of return that is relatively larger than the Philippines against the expected return.

In 2016, the performance of Indonesian banking stocks was below the Philippines. This is due to the domestic economic slowdown which is inseparable from the global economic recovery is still weak. Based on the report of the Central Statistics Agency (BPS), Indonesia's economic growth during the first quarter of 2016 only $4.92 \%$, lower than the fourth quarter of 2015 by $5.04 \%$. In addition, bank net profit decreased by $2.29 \%$ based on OJK data. The decrease in net income was also due to an increase in operating expenses. Because the real sector in the doldrums, the impact of lending also weakened. Until the third quarter of 2016, NLP is still on an upward trend. Data from Bank Indonesia (BI) noted the NPL ratio to 3.2\% by August 2016.
The Deposit Insurance Corporation (LPS) noted that the net interest margin (NIM) or net interest gain in national banking is still at the highest rate in the world at 5\%. This happens due to the growth of the banking business in Indonesia. In the period of November 2018, NIM Commercial Bank Business Activity (BOOK) IV recorded a rate of $5.77 \%$. NIM Indonesia including the highest rated. High NIM describes inefficiencies due to expensive venture production costs due to interest, in other words, credit is expensive. Compared to banks in ASEAN in the range of 1-2\%, due to costefficient due to good infrastructure networks and geographical conditions of a country. In addition, people are familiar with electronic money, credit cards, so that operating costs can be cheaper.

In 2018, bank credit growth in Indonesia has been on target which is $11.75 \%$ YoY. NPL ratio of the banking industry managed to a level of $2.37 \%$. Performance data bank fundamentals are in accordance with market expectations and even more. Throughout 2018, bank lending grew by double digits. This indicates a positive impact to the bank for successfully passing the unfavorable global conditions.

\subsection{Comparative Stock Performance Banking Indonesia And Philippines}

Of normality test results it can be concluded that all of the data in the study had a normal distribution. This is indicated by all the Sig count> 0.05 . Then it can be continued with different tests T-test was used to compare the average difference between the two different samples.

\section{Return}

Based on the results of data processing using SPSS, known to the Sig. $0.03<0.05$ means that there is a significant difference between the returns of banking stocks in Indonesia and the Philippines. Return Indonesia three times larger than the 
Philippines. This is in line with Indonesia's anticipation banking company better. Based on BEI report that Filipina market return in YTD 2018 decreased sharply by $12.76 \%$ compared to Indonesia just $2.54 \%$

\section{Risk}

Based on the results of data processing using SPSS, known to the Sig. 0.37>0.05 means that there is no significant difference in risk between Indonesian and Philippine banking stocks. Although Indonesia has a bigger risk. This is in line with Indonesia's Credit Default Swap (CDS) value of 103, which is still higher for the Philippines at 56

\section{Sharpe Index}

Based on the results of data processing using SPSS, known to the Sig. 0.17>0.05 means that there is no significant performance difference between Indonesia and the Philippines banking stocks. Although Indonesia has performed better. This is in line with the Indonesian banking stocks excess return greater than the Philippines for each unit of total risk so that the larger benefits of investing in Indonesia.

\section{Treynor Index}

Based on the results of data processing using SPSS, known to the Sig. 0.35>0.05 means that there is no significant performance difference between Indonesia and the Philippines banking stocks. Although Indonesia has a better performance. This is in line with economic growth in Indonesia was increased from $5.07 \%$ (2017) to $5.17 \%$ (2018). Meanwhile, the Philippines opposite from $6.7 \%$ to $6.2 \%$.

5. Jensen Index

Based on the results of data processing using SPSS, known to the Sig. $0.1>0.05$ means that there is no significant performance difference between Indonesia and the Philippines banking stocks. Although Indonesia has performed better. This is in line with the Chamber of Commerce reports that the Net Interest Margin (NIM) Indonesia is high in ASEAN, with a value of $5 \%$ and $3 \%$ Philippines.

\section{CONCLUSIONS AND RECOMMENDATIONS}

\subsection{Conclusions}

1. Banking Stocks Performance Indonesia and the Philippines

a. Performance Indonesian banking stocks have performed well (positive) in the period 20142018. Performs above the market and the banking company which is a large market capitalization in ASEAN

b. In general, Philippine banking stocks performed quite well. Although for the most part, the banking performance is negative or under market. Has a relatively low level of investment risk

2. Comparative Stock Performance Banking Indonesia and the Philippines

a. The comparison returns showed that the Indonesian banking stocks had an average return rate significantly higher than the Philippines during the period 2014-2018

b. The comparison showed that the risk of the Indonesian banking stocks has an average higher relative risk than the Philippines during the period 2014-2018. However, there was no significant difference.

c. The results of performance comparisons based on the Sharpe, Treynor, and Jensen indices show that the performance of Indonesian banking stocks is relatively better than in the Philippines for the 2014-2018 period. However, there was no significant difference.

\subsection{Recommendations}

1. Sharpe index when the market value or its performance is negative, then the use of this index measurement with potential to cause an error of interpretation. 
2. Using other ratios and duplicated data samples in order to increase research accuracy and to always monitor the dynamic development of the banking industry in accordance with ASEAN and global macroeconomic conditions.

3. Things that must be considered in order for Indonesia to enter $\mathrm{QAB}$ are maintaining a strong level of capital and having good fund management and corporate governance.

4. The performance of Indonesian banking stocks is better than that of the Philippines, however, Indonesian stakeholders must continue to improve Indonesia's economic fundamentals so that the investment risk perception indicator (CDS) can decrease.

\section{REFERENCES}

[1]. Akbar, R. J. (2018, July 9). PT. Viva Media Baru. Retrieved from https://www.viva.co.id/berita/bisnis/1052051saham-bank-bumn-masih-menarik-dikoleksiini-penjelasannya/

[2]. Sihombing, P. (2018). Corporate Financial Management. Bogor: IPB Press.

[3]. Bodie, Zvi, Alex Kane, \& Alan J. Marcus. 2018. Investments, 11th ed. Singapore: Irwin/McGraww-Hill.

[4]. Jogiyanto. (2003). Teori Portofolio dan Analisis Investasi. BPFE: Yogyakarta.

[5]. Reilly, Frank K., and Keith C. Brown. (2003). Investment Analysis and Portofolio Management, 7th ed. Mason: Thomson SouthWestern

[6]. Jones, Charles P. (2004). Investment. New Jersey: John Wiley and Sons (Asia) Pte Ltd.

[7]. Darmadji, T., dan Fakhruddin, H. (2006). Pasar Modal di Indonesia: Pendekatan Tanya Jawab. Jakarta: Salemba Empat.

[8]. Haugen, Robert. 1990. Modern Investment Theory 2. International Edition. Prentice Hall, Inc.
[9]. Jensen, M. 1968. The Performance of mutual funds in the period 1945-1964. Journal of Finance

[10]. Sujarweni, V. Wiratna. 2014. Metode Penelitian: Lengkap, Praktis, dan Mudah Dipahami. Yogyakarta: Pustaka Baru Press

[11]. Santoso, Singgih. 2007. Statistik Deskriptif: Konsep dan Aplikasi dengan Microsoft Exel dan SPSS. Yogyakarta: ANDI

[12]. Elliot, A. C., and Woodward, W. A., 2007. Statistical Analysis Quick Reference Guidebook With SPSS Examples. London: Sage Publications.

\section{Cite this article as :}

Arief Rahman, "Comparative Analysis of Performance Indonesia with the Philippines Banking Stock Using the Sharpe, Treynor, and Jensen Index ", International Journal of Scientific Research in Science and Technology (IJSRST), Online ISSN : 2395-602X, Print ISSN : 2395-6011, Volume 8 Issue 2, pp. 553-563, March-April 2021. Available at doi : https://doi.org/10.32628/IJSRST218298 Journal URL : https://ijsrst.com/IJSRST218298 | 